\title{
The Roman Mosaics of Bracara Augusta: Re-Reading and Reinterpretation of Decorative Motifs
}

\section{Bracara Augusta'nın Roma Mozaikleri: Dekoratif Motiflerin Yeniden Okunması ve Yeniden Yorumlanması}

Fátima ABRAÇOS - Licínia WRENCH*

(Received 02 November 2016, accepted after revision 07 March 2017)

\begin{abstract}
The earliest news about mosaics discovered in the Roman city of Bracara Augusta, dating from the second half of the nineteenth century, were mostly published in local newspapers. Only in 1976, after the creation of the Archaeological Field of Braga, the body responsible for carrying out rescue archaeology in the urban area, were some dozens of archaeological interventions performed, which allowed mapping, safeguarding remains and proceed a cultural heritage. This allowed us to have a systematic knowledge of the mosaics of Bracara Augusta.

Our work aims to provide an overview of the mosaics displayed in D. Diogo de Sousa Museum of Braga and remaining in situ (the mosaic of "Escola Velha da Sé" (Cathedral's Old School) and the mosaic of the "Casa da Roda" (House of the Wheel), to undertake a new reading and interpretation of them, looking for their relationships with the mosaics of the eastern and western Mediterranean.
\end{abstract}

Keywords: Bracara Augusta, Roman mosaics, patterns, decorative motifs, re-reading.

$\ddot{\mathrm{O} z}$

Bir Roma kenti olan Bracara Augusta'da çoğunluğu 19. yüzyllın ikinci yarısına tarihlenen mozaiklerle ilgili ilk bilgiler yerel gazetelerde yayınlanmıştır. Ancak 1976 yılında, Braga Arkeolojik Alan Projesi ile, kentsel alanda kurtarma kazılarının üstlenilmesi, birçok arkeolojik çalışmanın gerçekleștirilmesiyle haritalama, kalıntıların korunması ve kültürel mirasa kazandırılması mümkün olabilmiştir. Bu sayede, Bracara Augusta'nın mozaikleri hakkında sistematik bir bilgiye sahip olunmuştur.

Bu çalışmada, D. Diogo de Sousa Müzesi-Braga'da sergilenen mozaikler ile in situ olarak korunan "Escola Velha da Sé” Mozaiği (Eski Kathedral Okulu) ve "Casa da Roda” (Çark Evi) mozaikleri ele alınarak yeniden okumaları ve yeniden yorumlamaları yapılacak, aynı zamanda Doğu ve Batı Akdeniz'deki mozaiklerle ilişkileri irdelenecektir.

Anahtar Kelimeler: Bracara Augusta, Roma mozaikleri, desenler, dekoratif motifler, yeniden okuma.

Since the 1970's, some of the archaeological interventions undertaken by the archaeological team of the City Council of Braga and the Recovery Team of Bracara Augusta, under the responsibility of the Archaeology Unit of Minho University, have revealed a set of information which has allowed the reconstitution of the urban development of Bracara Augusta ${ }^{1}$ (Fig. 1).

\footnotetext{
* Maria de Fátima Abraços, Instituto de História da Arte - Faculdade de Ciências Sociais e Humana, Universidade Nova de Lisboa, Av. de Berna, 26-C1069-061 Lisboa, Portugal. E-mail: maria.abracos1951@gmail.com

Licínia Wrench, Instituto de História da Arte - Faculdade de Ciências Sociais e Humanas, Universidade Nova de Lisboa, Av. de Berna, 26-C1069-061 Lisboa, Portugal. E-mail: wrench.licinia@gmail.com

1 "Based on the available archaeological remains, it is possible to note that the city had axles oriented 1 actus (120 feet), observable modulation in the archaeological area of Carvalheiras (Martins 2004: 154). The city streets measure between 10 to 12 feet, having been identified, so far, a single road with 25 feet wide, which allowed access to the forum." (Magalhães 2015: 18).
} 


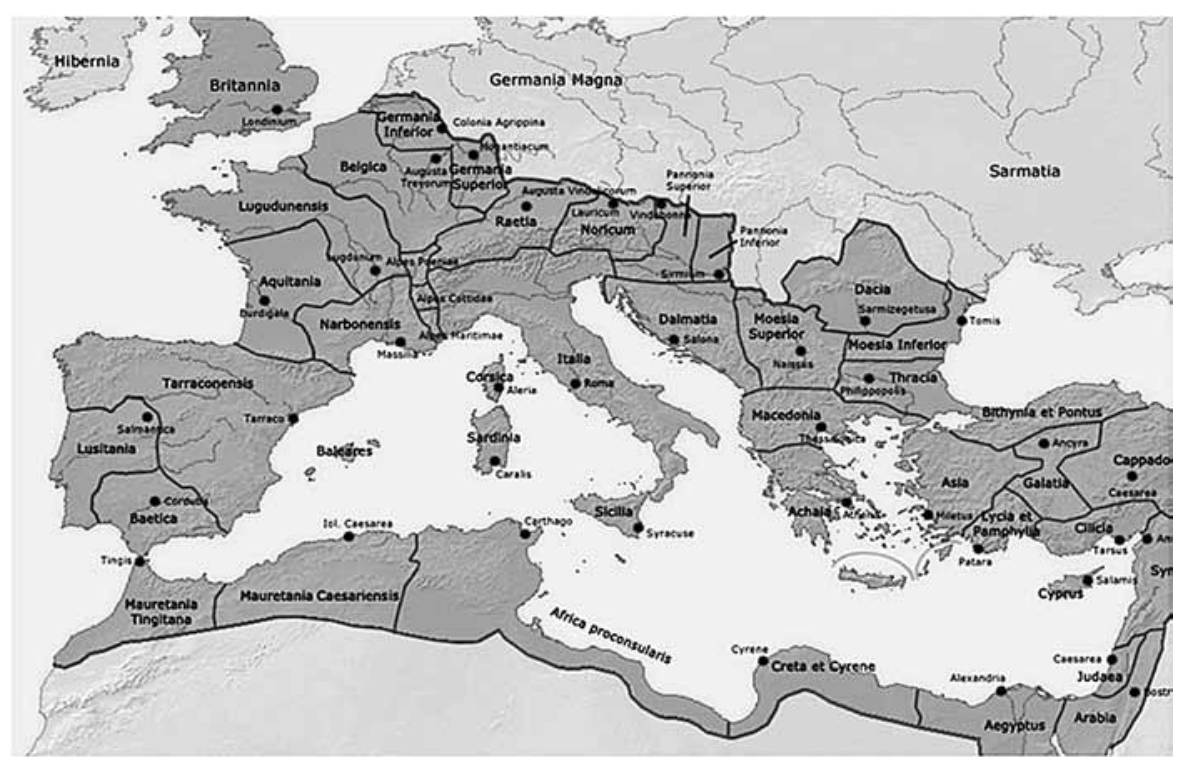

Among the different archaeological sites already excavated a set of old domus has been selected for being in a central area of the Roman city. Some of these domus have been paved with mosaic in different periods of their occupation. Supporting this choice is the attempt to find and interpret a repertoire of the geometric patterns present on the mosaic fragments discovered in these houses.

These interventions have brought to our attention a number of mosaic floors which we have been studying and publishing ${ }^{2}$. Between the last quarter of the first century and early second century, a programme of works, well testified by the important remains of public and private buildings, was carried out in the city. In this period, the city would have reached its maximum extension. In the following period, between the end of the second century and mid-third century, the city knew some stagnation in terms of construction. However, the city registered again an important programme of urban renewal, between the end of the third century and the beginning of the fourth century, a period during which the city acquired a greater importance in the context of the cities in the northwest of the Peninsula, with its elevation to capital of the new province of Gallaecia. In this period, important renovations on public and private buildings were carried out,
Figure 1

Location of Bracara Augusta, capital of Conuentus Bracaraugustanus, northwest of Hispania.

(Google earth)

2 See Bibliography: Abraços 2005; 2008; 2011; 2014; 2015; 2015a; Abraços in print and Wrench 2014; Wrench in print.

Since the beginning of the nineties, when we integrated the project of the Corpus of Roman Mosaics in Portugal, directed by Janine Lancha and Adília Alarcão, we realized the lack of a specific study on conservation and restoration and an updated inventory of Roman mosaics discovered in the Portuguese territory. Due to this, in 2001, we presented to the Faculty of Letters of the Classic University of Lisbon a Doctoral research project that included the study of the mosaics in the whole territory. We elaborated a work (Ph.D. thesis) divided into 3 volumes (Abraços 2005). In the first volume, we drew a brief perspective of the history of the mosaic, conservation practices, lifting techniques, consolidation, conservation and restoration of the mosaics in Portugal up to the recent methodologies and the best preventive solutions; we looked to do a review of the situation in relation to the state of conservation of the mosaics in museum collections and of mosaics in situ. In the second volume (Annex I), we presented the study of the mosaics of museum collections, described in 429 files, with graphic and photographic documentation according to the model of files from the Corpus of Roman mosaics in Portugal. In the third volume (Annex II), we introduced the Roman mosaics from archaeological sites in the Portuguese territory, those in situ, in museums or in private collections, for a total of 254 sites with mosaic floors and 832 fragments of mosaics. Since that, we have been completed this inventory in partial studies published in specialized magazines or in the proceedings of Congresses (Abraços 2008; 2011; 2014; 2015; 2015a); Abraços in print). Our objective is to collect this mosaic heritage, systematically studying and giving it continuity, including the new findings within a corpus: "The Corpus of Roman mosaics from Conuentus Bracaraugustanus". To reach this goal we are developing a project with other researchers. 


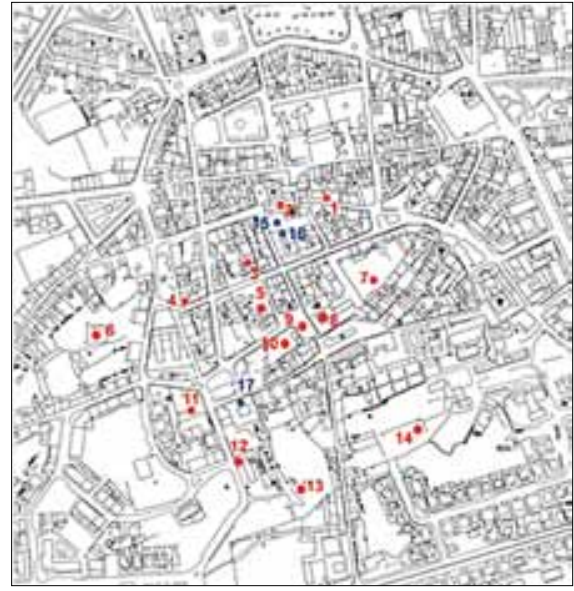

Figure 2

City Map of Braga. Location of the archaeological sites with mosaics analysed. 1 - Casa da Roda, Rua de S. João; 4 - Rua D. Afonso Henriques, 1 (Escola Velha da Sé); 5 - Rua D. Afonso Henriques, 20-28. (C) AMDDS. with a powerful wall being built, very well documented by the archaeological remains from different excavations.

The late imperial city is characterized by a building dynamic that led to the narrowing of the roads and to the disappearance of some of them. On the other hand, the refurbishment of the houses registered some loss of orthogonality, failing to respect the characteristic orientation of the early imperial city. This tendency persisted in the buildings of the fifth century, a period during which the city became the capital of the Suebic Kingdom. (Ribeiro 2008: 265)

In addition to public buildings, the city had its residential quarters where prestigious domus were built, attesting to the richness of the urban population, well documented through their late renovations, generally characterised by the introduction of balnea and mosaic floors (Magalhães 2010: 19-21).

In most cases, it has been the practice to lift the mosaic fragments and direct them to the Conservation and Restoration Team of the D. Diogo de Sousa Regional Archaeological Museum (MDDS), in Braga, where, after treatment, the fragments are deposited for later studies; other fragments, whose conditions of protection allow them to stay integrated in the architectural structures where they were discovered, remain in situ (Fig. 2).

The mosaics that we are going to present remain in situ the Mosaic of "Escola Velha da Sé" (Cathedral's Old School) and the Mosaic of the "Casa da Roda" (House of the Wheel).

\section{The mosaic of the "Escola Velha da Sé" ("Cathedral's Old School"), D. Afonso Henriques Street, $\mathrm{n}^{\circ} 1$}

In 1998, due to a proposed remodelling of the building of the former "Escola Velha da Sé" an archaeological intervention was carried out by the Archaeology Office of the City Council of Braga, under the direction of Armandino Cunha, whose works took place during different phases up to 2003.

The area of intervention, located in the underground of the building, occupies a total area of $720 \mathrm{~m}^{2}$, where the southern part of a Roman house with remains of a hypocaustum and floors covered with tiles and mosaics was uncovered (Fig. 3). Three phases of construction were distinguished for this house, based on the stratigraphy and the archaeological materials analysed. The first phase can be dated from the first century and it is represented by the several walls that define the rooms that relate to the private part of the building. The second phase corresponds to a significant remodelling of the house, which can be dated between the late third century and the early fourth century (Fig. 4). The remodelling of the domus that defines this second phase of occupation was characterized by the construction of baths, in the southwest area of the building. The construction of the baths complex sacrificed the area of the house previously occupied by a possible peristylum. Related to this remodelling, there is a mosaic pavement which

\footnotetext{
3 Most of the Roman mosaics of Conuentus Bracaraugustanus, discovered from 1883 onwards, were found in architectural structures in the area of the city of Braga: City; Seminary of Santiago; Cerca; Cardoso da Saudade/ Quintal of Fernando Castiço; Carvalheiras; Casa da Roda (House of the Wheel); Cathedral; Gualdim Pais Street Block; Quinta of Fujacal; D. Afonso Henriques Street n. 1; 20-28 and 42-56; Cavalariças (Horse stables) in the area of the D. Diogo de Sousa Museum and also in $\mathrm{S}$. Martinho of Dume (2 Km north of Braga). It is already known that there are two dozen sites with mosaics. These interventions have allowed the documentation of the orthogonal layout of the Roman city and the characterization of their public and private equipment.
} 

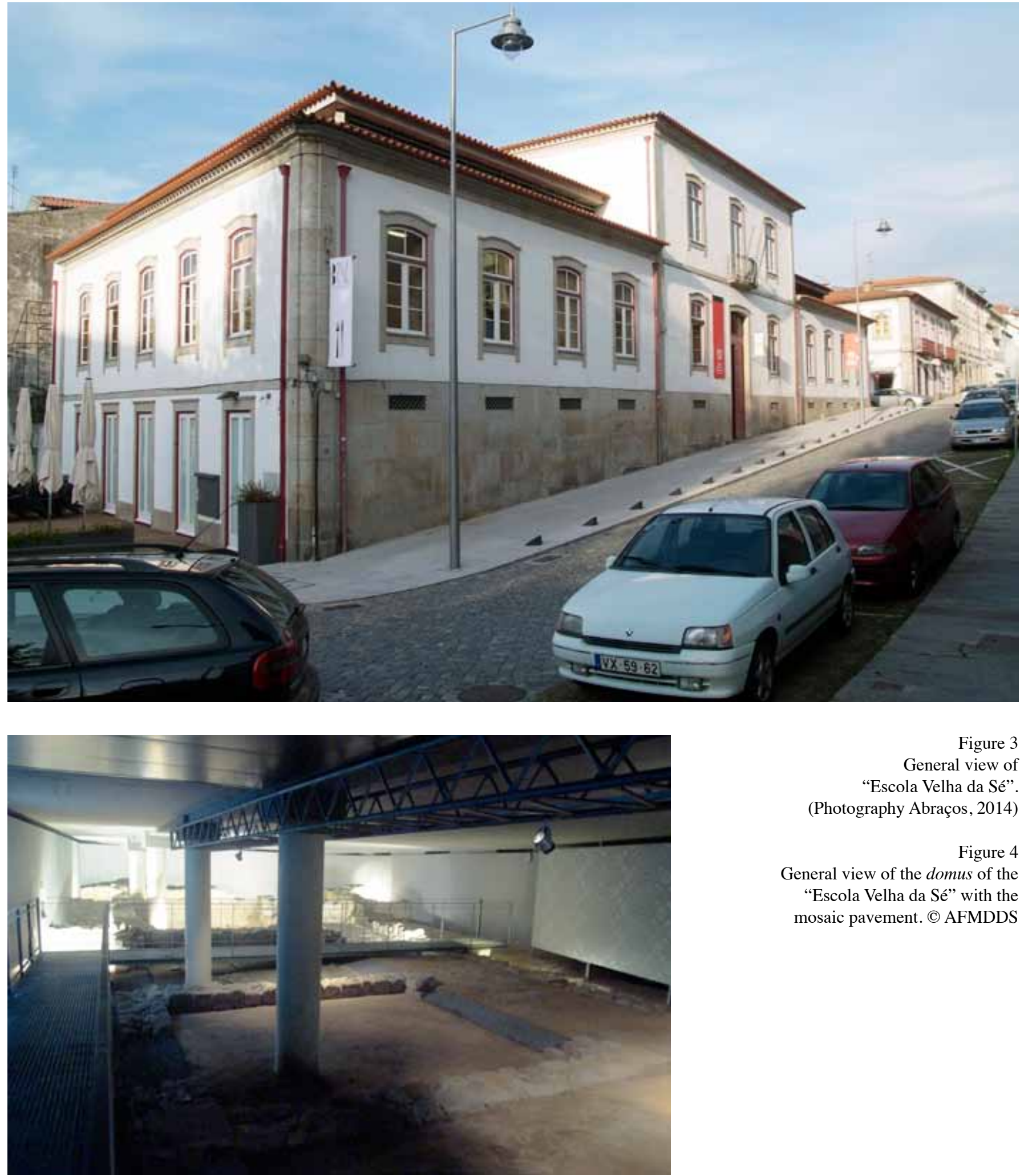

Figure 3

General view of "Escola Velha da Sé". (Photography Abraços, 2014)

Figure 4

General view of the domus of the "Escola Velha da Sé" with the mosaic pavement. (C) AFMDDS

covered an extensive corridor and allowed access to the new area of the house, enabling the interaction of the baths space with the other rooms of the house (Magalhães 2010: 50-51) (Fig. 5).

This mosaic of bicolour tesserae (black and white limestone) is decorated with geometric motifs (Fig. 6). The connection of the mosaic carpet with the walls 
Figure. 5

General view of the mosaic from the domus of the "Escola Velha da Sé". (c) AFMDDS

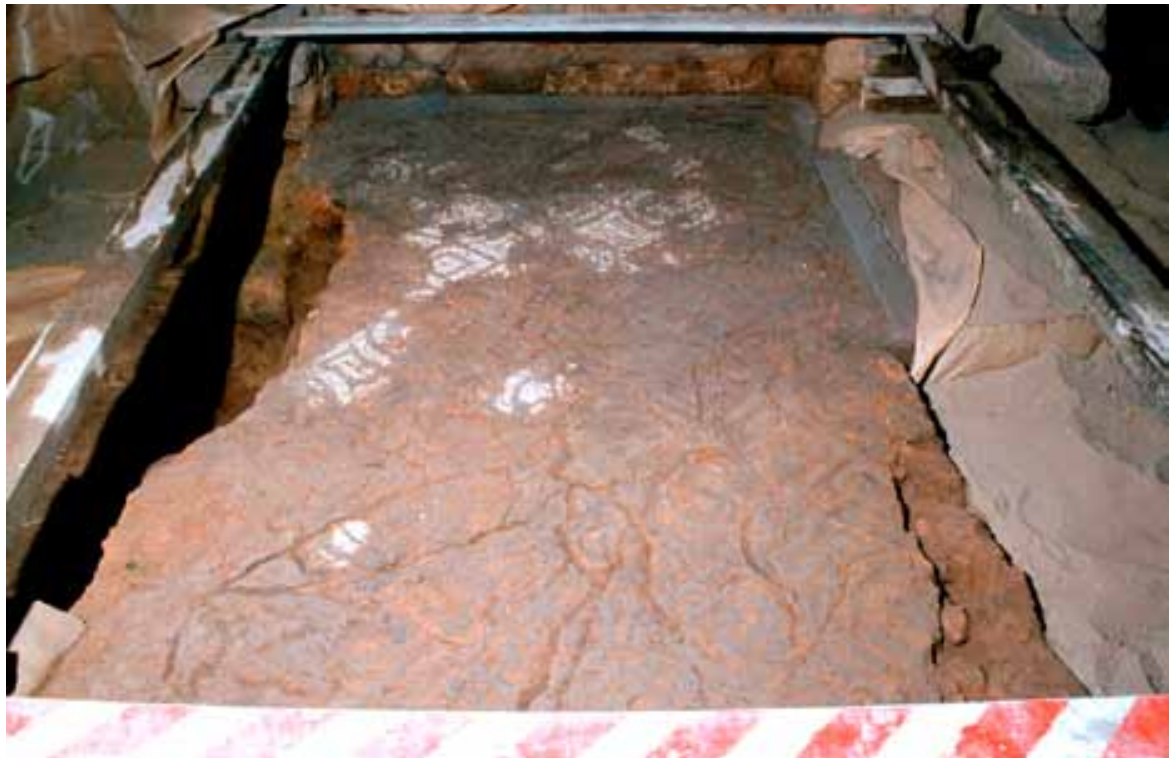

is made through a frieze of $1 \mathrm{~cm}$ white tesserae ${ }^{4}$. The compositional scheme, "orthogonal pattern of tangent outlined circles and poised squares, forming bobbins" (Décor I: pl. 156a), would have spread in the western part of the Empire since the second century AD, occurring in mosaics from Switzerland, Germany and France. It would be a variety of a diagonal grid - cancellum - a pattern known in Pompeii since the first century BC. This pattern evolved into the composition in which the circles alternate with the squares occurring in the first half of the second century AD in an example at Aquileia (Lancha 1977: 98). In Hispania, as well as in North Africa, this scheme had a wide dissemination until a quite late period.

In this mosaic from Braga, black and white, the scheme occurs with considerable visibility and the filling decoration slightly emphasized (Fig. 7). The squares are outlined by a double filet of black tesserae, enclosing squares with a central small square. The circles enclose circles bearing a kind of an irregular corolla with a central small square of poised tesserae, or alternately bearing black or white small squares. The rectangles with facing pairs of concave and straight sides (bobbins) enclose, also, a bobbin.

In mosaics from the Portuguese territory, we find a similar composition, decoratively more simplified, in two side panels of the triclinium figured mosaic of the Villa of Alter do Chão, Portalegre, Conuentus Emeritensis. It is "an orthogonal scheme of white concave circles and squares, with blue filling. From the tangency of these elements, double-axes result with ochre filling and differentiated guidelines. It is also important to point out that the circles are centred in crosses made of five white tesserae and the squares filled only by one white tessera." The geometric mosaics from this uilla were dated, in genere, from the thirdfourth century (António 2015: 46, 49-50 fig. 13).

In the Villa of Coriscada, Meda (Légier 2015: 193 fig. 9) the same scheme from the mosaic of Braga is used in wide bands enveloping the figured panel, dated from the third-fourth century. Although the decoration in the circles

4 In addition to this mosaic, in the neighbouring rooms, other small fragments with tesserae of various colours have been identified, but due to their fragmentation, it has not been possible to characterize them. (Magalhães 2010: 57). 


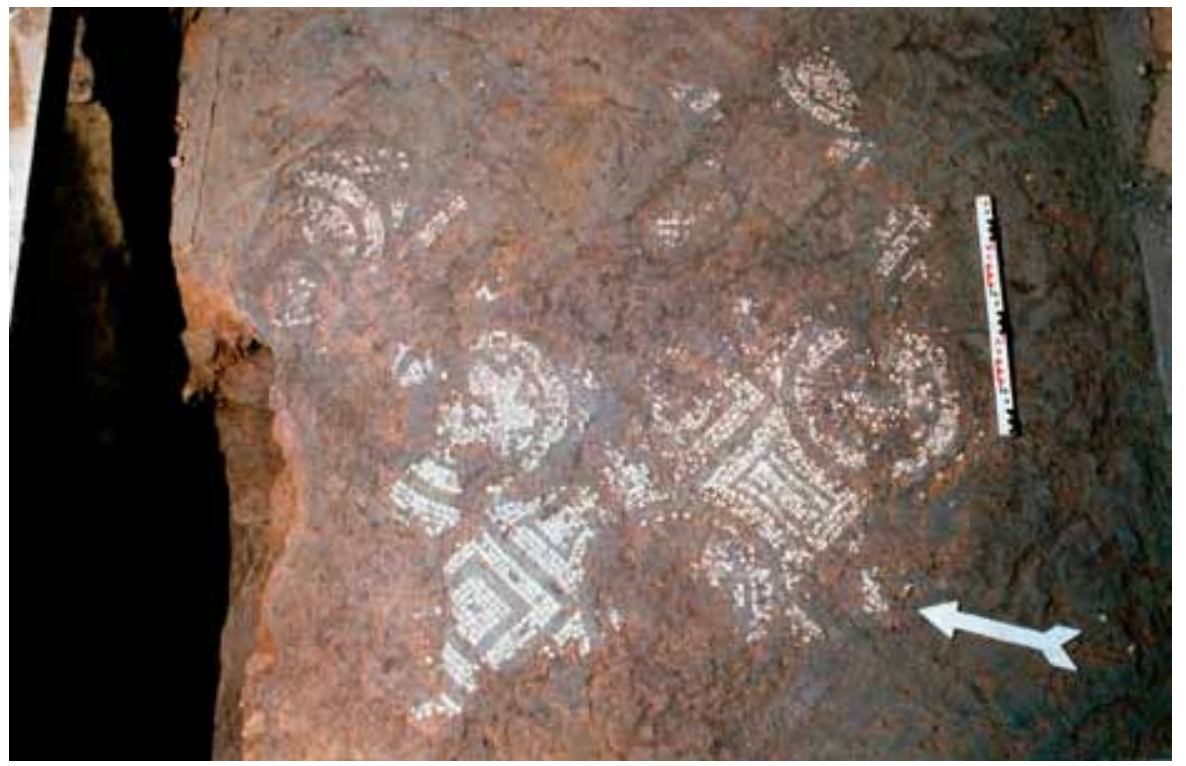

Figure 6

Partial view of the mosaic from the domus of the "Escola Velha da Sé".

(c) AFMDDS

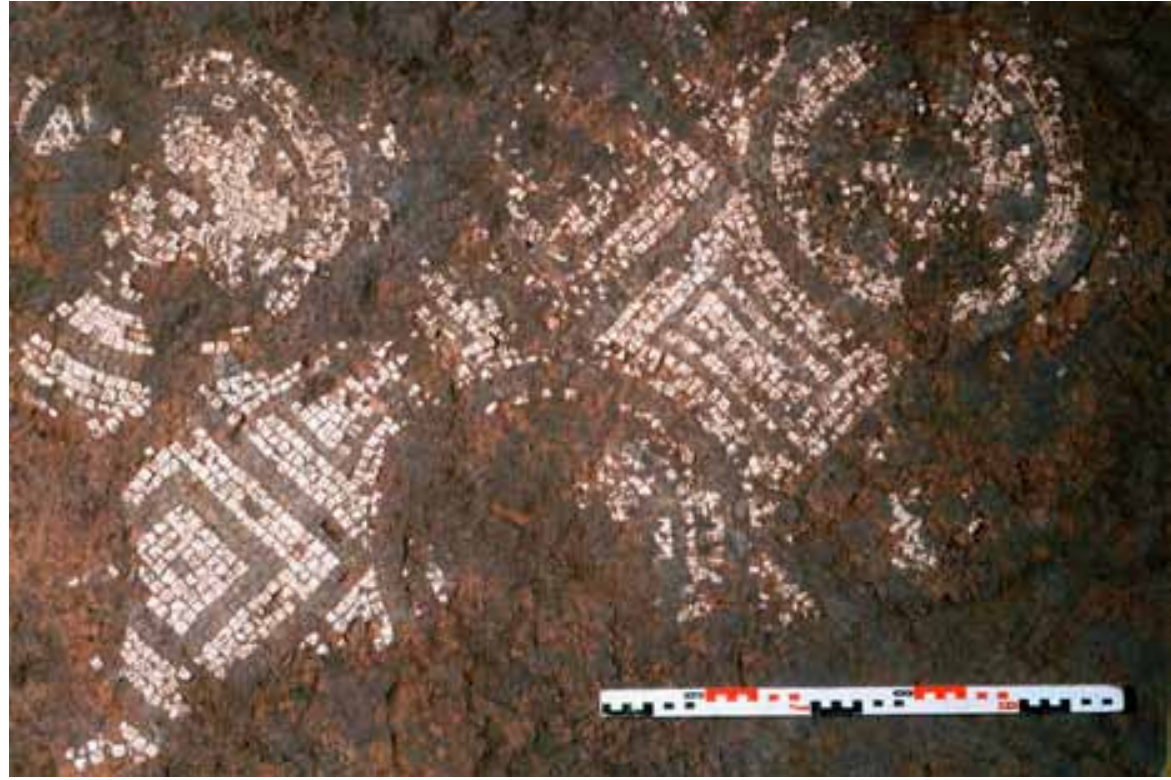

Figure 7

Detail of the pattern decoration of the mosaic from the domus of the "Escola Velha da Sé".

(c) AFMDDS

is more emphasized than the one featured in the mosaic of Braga (Cathedral's Old School) they are quite similar. Also very similar to the mosaics of Braga and Coriscada is the mosaic fragment from the Villa of Boca do Rio, Budens, conserved in the Santos Rocha Museum, from Figueira da Foz, with inventory number: MMSR 4227 (Abraços 2005: annex I 68-69). The same scheme, with a simple guilloche involving the circles and squares, occurs once again in a mosaic of the Villa of Santiago da Guarda, Ansião, Leiria, Conuentus Scalabitanus (Ribeiro 2015: 88 fig. 14). The mosaics of this uilla are dated from the end of fourth century to the beginning of the fifth (Pereira 2008: 174).

In Spain, we begin by highlighting the Roman province of Galaecia, where the same scheme appears in Doncide and, probably, in Centroña (Torres Carro 2015: 214).

In the northern Meseta, this scheme is quite frequent, especially in late mosaics (Monteagudo et al. 1998: 29). In the province of León, in a black and white mosaic from Calzada del Coto, dated from the second-third century, the scheme 
is used with decorative simplicity, exclusively geometric (Blázquez et al. 1993: 20-21 mosaic n. 4 fig. 4 lam. 3); with more emphasized ornamentation, bearing rosettes in the circles, with the scheme in a simple guilloche, a mosaic from the Campo de Villavidel in a uilla dated from fourth century (Blázquez et al. 1993: 23-24 mosaic n. 6 (south room mosaic) fig. 6 lams. 6 and 25). Also executed in a simple guilloche, the same scheme is featured in a mosaic from Cardeñajimeno (Burgos), corresponding to the floor of a room close to a hypocaustum, maybe belonging to the uilla's baths, dated from the late fourth century (Monteagudo et al. 1998: 29 mosaic n. 11 lam. 14).

In the Villa of Prado (Valladolid) the scheme is used as a band of the pavement number 2, chronologically corresponding to the expansion phase of the uilla in the fourth century (Torres Carro 1988: 181-192; 201-202 fig. 3 lams. II-III). ${ }^{5}$

We can see the same pattern, circles and squares in a simple guilloche, in the mosaic of Liédena (Navarra), in room 13, dated from the third century (Blázquez - Mezquiriz 1985: 44-48 mosaic n. 24 lams. 28-29; Mezquíriz 2004: 344 lam. $\mathrm{XV})$ and, in the same uilla, with a simpler decoration, in black and white, in a panel on the south side of the peristyle (Mezquíriz 2004: 335-336 fig. 9 lam. IX, 1). With a more emphasized ornamentation, the scheme is used in a mosaic from Valencia de Alcántara (Caceres), from the late third century or early fourth (Blázquez et al. 1993: 23). In other late imperial mosaics with an emphasized horror uacui the same pattern occurs, among other examples: in a mosaic from Cuevas de Soria (Blázquez - Ortego 1983: 63-65 mosaic n. 55 fig. 6), in which the sequential decoration of bobbins creates the effect of crossed bands with poised squares at the intersections, and ensconced circles ${ }^{6}$; in a mosaic from Azuara (Zaragoza); in a mosaic from Saint Cristina de la Polvorosa (Zamora) and, with some variation, like the substitution of the squares by octagons with concave sides, in a mosaic from Complutum, as the composition envelopes the central panel with the depictions of Leda and the swan/Jupiter, from the late fourth or early fifth (Fernández Galiano 1984: 213 Zeus and Leda mosaic fig. 13); from Alcázer de San Juan (Ciudad Real), in a mosaic conserved in the Fray Juan Cobo Museum, dated from the fourth century, with a varied filling decoration of different geometric figures, with the circles of the composition as laurel wreaths (Blázquez 1982: 17 mosaic n. 21 fig. 17); from Talavera de la Reina and from the Villa of Las Tamujas, Malpica de Tajo (Toledo) (Blázquez 1982: 43-47 mosaic n. 31 fig. 21 lam. 35 and mosaic n. 33 fig. 22; Blázquez et al. 1993: 23).

Even later than in the above mentioned uillae, the same scheme is used in the mosaic of the church choir of San Pedro in Egara (Terrassa), Catalonia, showing us "the passage into the medieval world and, at the same time, the survival of the ancient world" (Barral i Altet 1975: 257 pl. XCVIII).

In North Africa, this scheme is also well documented, with, sometimes, the simple guilloche replaced by garlands of laurel leaves, with examples from the midsecond century, from El Djem; from the third century, in Utica, an example of a black and white mosaic of the "Maison de la Cascade", corridor XII (Alexander - Ennaïfer 1975: $37 \mathrm{pl}$. XIV); from the fourth century, from Thuburbo Maius, from Leptis Magna or the examples from the Christian Basilicas of Sabratha (Blázquez et al. 1993: 23)7.

\footnotetext{
5 The enveloping band shows a row of circles and tangent poised squares, framed by a simple guilloche. The mosaic field presents a centralized pattern, with the corners bearing a crater.

6 The authors point out to the composition of bands with squares and circles, among other examples, a mosaic from the uilla of Abicada, Portimão (Portugal).

7 For the mentioned African mosaics, the authors quote the corresponding bibliography.
} 


\section{The Mosaics of D. Afonso Henriques Street, N. 20-28}

At the XIII AIEMA Conference held in Madrid in 2015, for the first time, a brief description was presented of the mosaic fragments that were discovered in the building of D. Afonso Henriques Street, numbers 20-28 (Abraços in print). The archaeological excavations carried out in this site have revealed a more or less continuous occupation since the last quarter of the first century $\mathrm{BC}$ until the end of the twentieth century, as proved by the construction phases presented in the excavation report. From that set, it is important to give relevance to phases I, II and III, whose structures focus on the northeast corner of a Roman insula, where numerous fragments of multi-coloured mosaics were collected, having been deposited as debris from the documented remodelling in phase III and that show the existence of houses with mosaic paving and late Empire dating ${ }^{8}$. The numerous fragments of the mosaic were raised and directed to the MDDS, where they were cleaned and consolidated.

Recent bibliography invites us to complete, with a new approach, the themes of this mosaic. These fragments are part of the same mosaic, where circular medallions are predominant, outlined by white bands, four tesserae wide, bearing rosettes composed of white, ochre, yellow and pink tesserae over a black tesserae background. From this set, we highlight a fragment which features a unitary rosette of four (4) non-contiguous elements, as lanceolate petal with volutes, here the centre as a circle (Décor II: pl. 255f, variety). The density of the tesserae is $135 / \mathrm{dm} 2$ (Fig. 8). This rosette is similar to the one number XII $b$ from the Ocean mosaic from Faro. Janine Lancha and Cristina Oliveira (Lancha - Oliveira 2013: 212) while describing the rosettes from the Ocean Mosaic, refer the existence of stylistic approaches to rosettes from North Africa and claim that the likely source of these rosettes would have come from an African officina.

All rosettes that are identifiable in this set of fragments discovered in Braga belong to the category of unitary rosettes with one corolla and appear integrated in an outlined orthogonal pattern of tangent circles, forming poised concave squares (Décor I: 233, variety) with parallels in North Africa and dating from the third-fourth century $\mathrm{AD}^{9}$.

Mercedes Torres Carro, by analysing the geometric structure of the decoration of the antechamber mosaic from the ocus of the Domus Oceani of Lugo, similar to the composition of the Braga mosaic, infers that the sources of inspiration and learning of the Lugo's officina would have been imported from North Africa, more specifically, from places like Cherchel, Thuburbo Majus and Timgad (Torres Carro 2015: 336).

Another fragment of the same mosaic shows a circular medallion of about $70 \mathrm{~cm}$ in diameter, in a polychrome simple guilloche which presents the partial bulge of a crater with a very rudimentary base (Fig. 9). A kind of volute is visible in white tesserae on either side of the base of the crater. We found the exact parallel for the base of this vase in a mosaic in the church of Zahrani, in Lebanon (Balty 1995: 374). The craters could be used in different types of compositions, but the most common was the positioning in the angles; it was also very much used in the centre of the apses or in the central medallions (Lancha-Oliveira 2013: 232). That may be the case with the crater represented here.

8 Leite et al. 2012: Archaeological works from UAUM/Memoirs, 25, 2012, Excavation report of 2009 fig. 2. (repositorium.sdum.uminho.pt/bitstream/1822/19004/1/Memorias_25. pdf).

9 In relation to the rosette, see Thuburbo Majus, Tunisia, Alexander et al. 1980: 1, n. 42 A, pl. XXIII. 

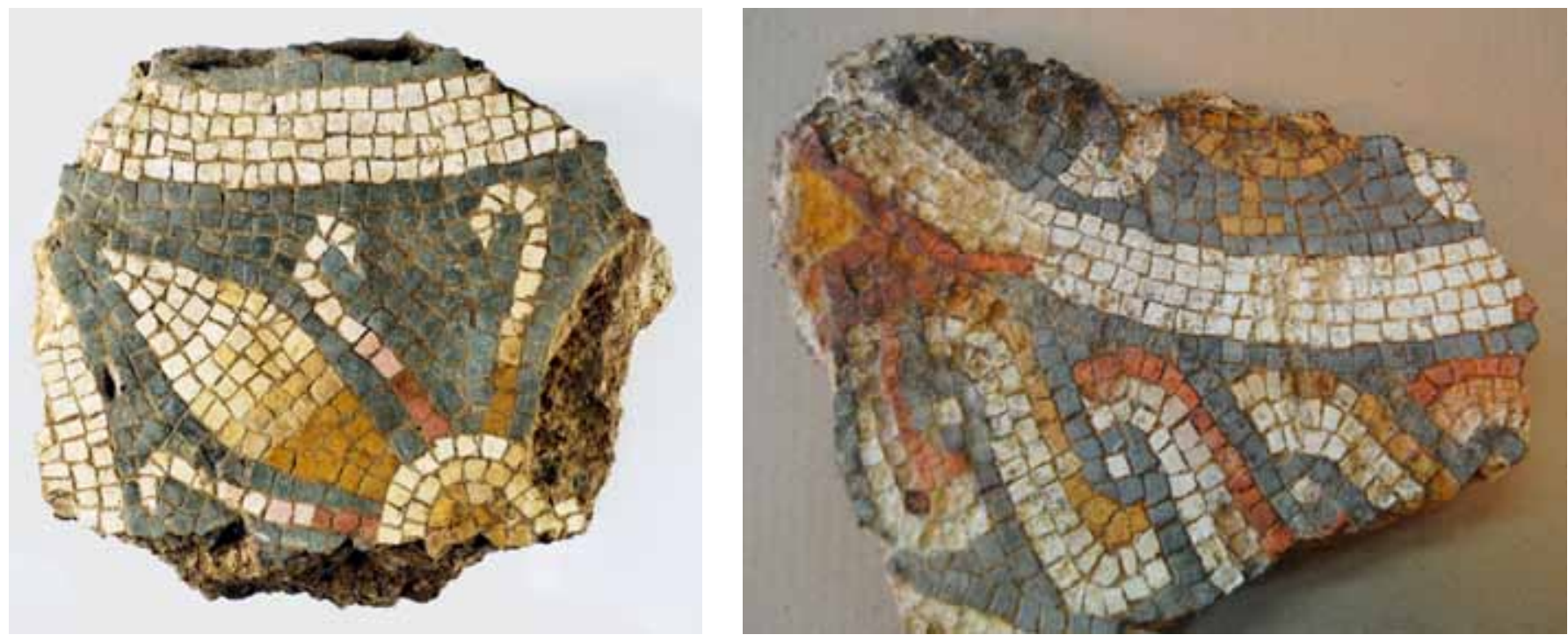

Figure 8

Mosaic of D. Afonso Henriques

Street, numbers 20-28.

Fragment with a rosette $(25 \mathrm{X} 22 \mathrm{~cm})$. (C) AFMDDS

Figure 9

Mosaic of D. Afonso Henriques Street, numbers 20-28.

Fragment decorated with crater. $(23 X 30 \mathrm{~cm})$. (C) AFMDDS
This mosaic of Braga is very interesting due to the repertoire of illustrated rosettes in a composition of circles, as well as to the presence of a crater. Until this moment, it is the only mosaic from Conuentus Bracaraugustanus with the representation of a vase, which associated with rosettes, can refer us to different meanings (Dionysian? Christian?).

\section{The Mosaic of the "Casa da Roda" (House of the Wheel), San John Street, Braga (Figs. 10-11)}

The mosaic of the "Casa da Roda" was mentioned for the first time by Fátima Abraços (Abraços 2005: 218-219; Annex I: 339-340). It remains in situ, covered with a suitable material, after being consolidated by the Team from the D. Diogo de Sousa Museum and inventoried with number 2003.0515 (Fig. 12). We had the opportunity to approach it, together with other Portuguese mosaics, in the context of the first International Olympos (Uludağ) Studies Workshop, held in Olympos in 2014 (Wrench 2014: 49-59) and deepen the analysis of the same mosaic in the context of the XIV AD SAECVLVM AVGVSTVM International Conference, held in Lisbon in 2014 (Wrench in print).

Therefore, we have already had the opportunity to describe and analyse, in comparison with other mosaics, the geometric themes present in it, pointing as likely chronology for its execution the end of the third century to the beginning of the fourth century, a period in which Bracara Augusta undertakes considerable constructive works, after its passage to capital of Galaecia (Wrench 2014: 57).

In this text, we will highlight some stylistic aspects and make reference to a few more parallels which meanwhile we noted (Fig. 13).

Concerning the frame of an undulating row of alternately inverted peltae with hederae on the apices (Décor I: pl. 58e, variety) and its use in mosaics of the Portuguese territory, we mention the example of the mosaic of Martim Gil, Leiria, Conuentus Scalabitanus, with probable dating from the fourth century (Costa 1905: 49-50; Correia Wrench 2005: 65-67 fig.19 est. 23), and the frames of three mosaics from the Villa of Quinta das Longas, Elvas: mosaics from rooms numbers 12 and 17, with trilobe hederae, dated from the early fourth century and the one from the apse of room 5, dated from the early fifth century (Oliveira et 


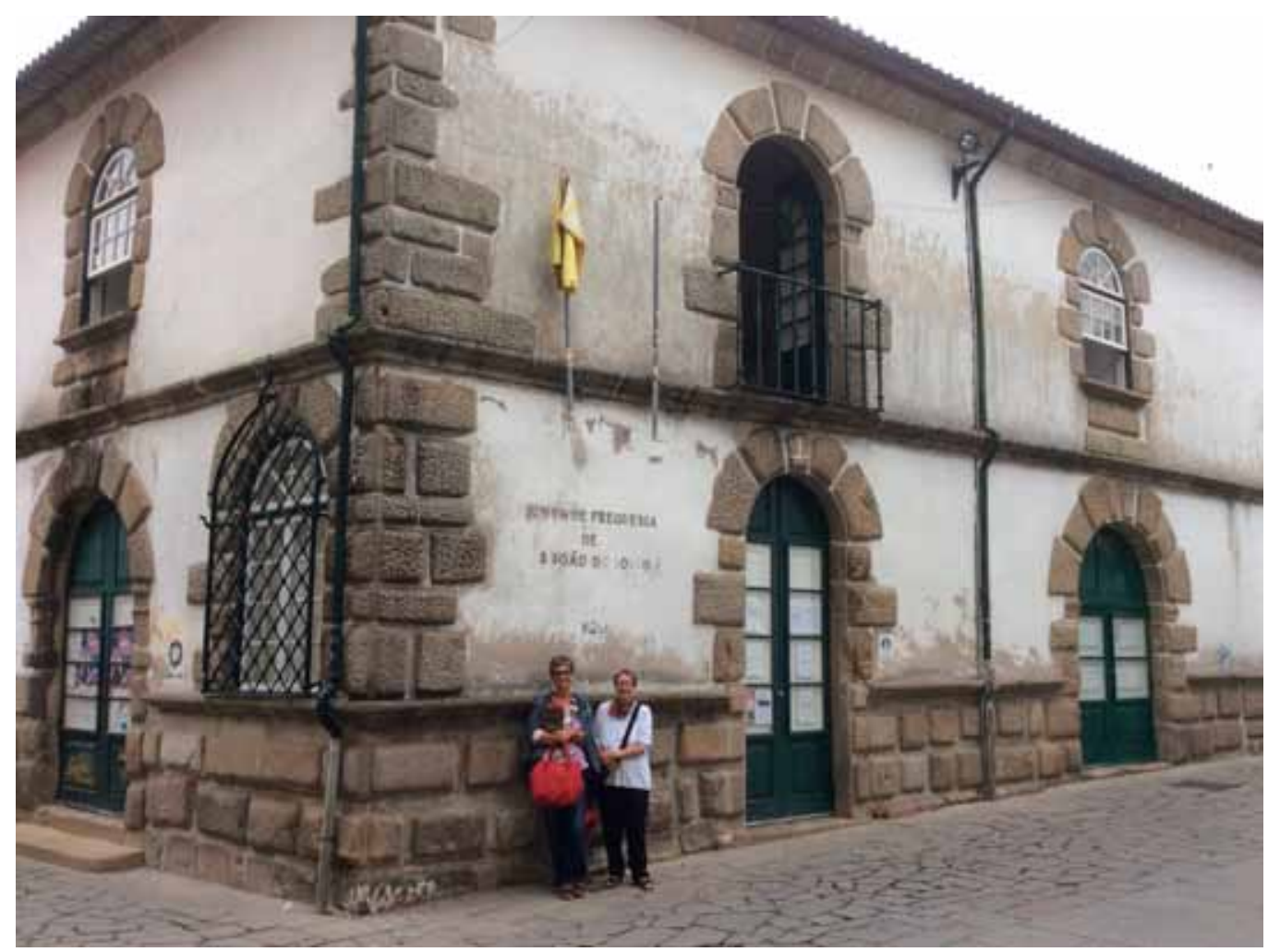

Figure 10 General view of the "Casa da Roda". (photograph of the authors)

al. 2011: 907-908 figs. 10, 13, 16). Another Portuguese example of frames of alternately inverted peltae with a heart on the central point comes from Mértola, from the area of the forum/citadel, as the band of a much destroyed panel, near the one of the defied Lions, in mosaics dated from the Justinian period (Lopes 2003: 106-107 fig. 74; Lopes 2015: 27 fig. 4). It is important to note that in the mosaic of the "House of the Wheel", as in the examples of the Villa of Quinta das Longas, the side points of the peltae are united by a small group of tesserae, interrupting the undulating row that appears continuous in other examples of Portuguese mosaics with an undulating line of peltae. The same individualisation of each pelta through a group of tesserae is used in the mosaics of Soria

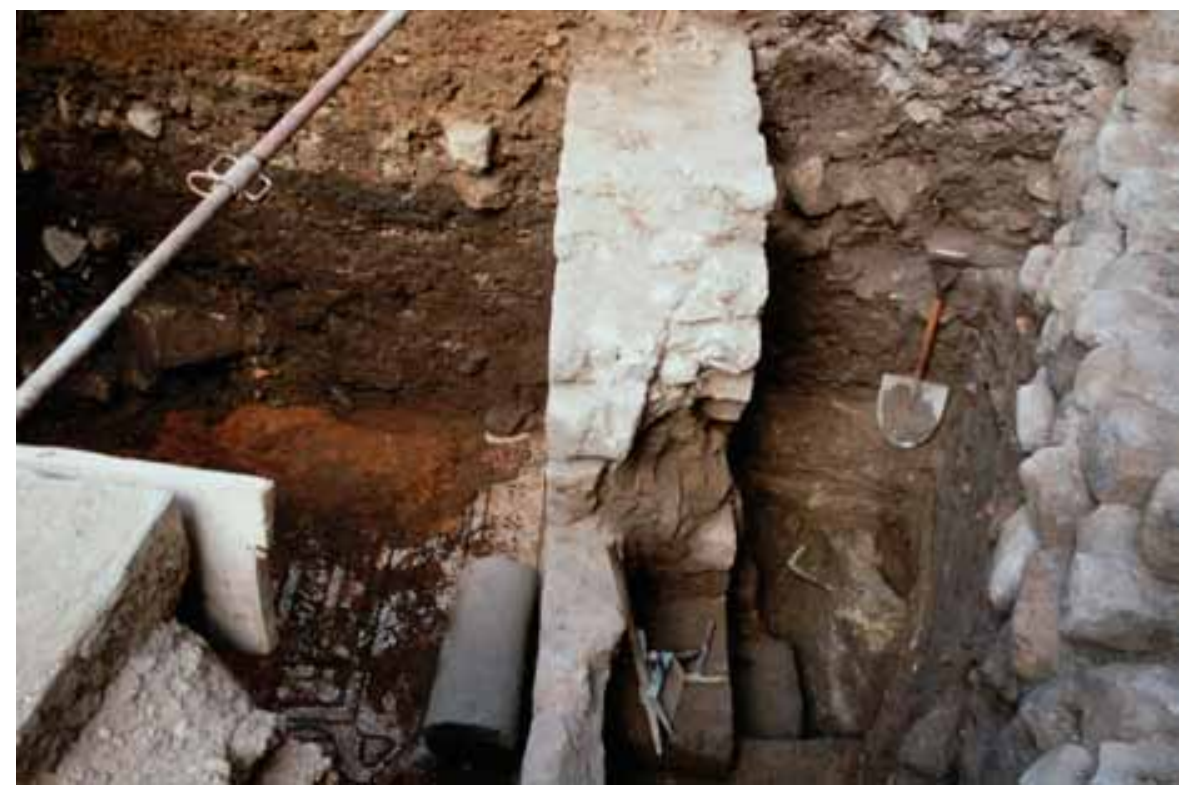

Figure 11

Detail of the Mosaic from the "Casa da Roda" (House of the Wheel). (C) AFMDDS 
Figure 12

General view of the mosaic from the "Casa da Roda". (C) AFMDDS

Figure 13

Detail of the band with inverted peltae of the mosaic from the "Casa da Roda". (C) AFMDDS
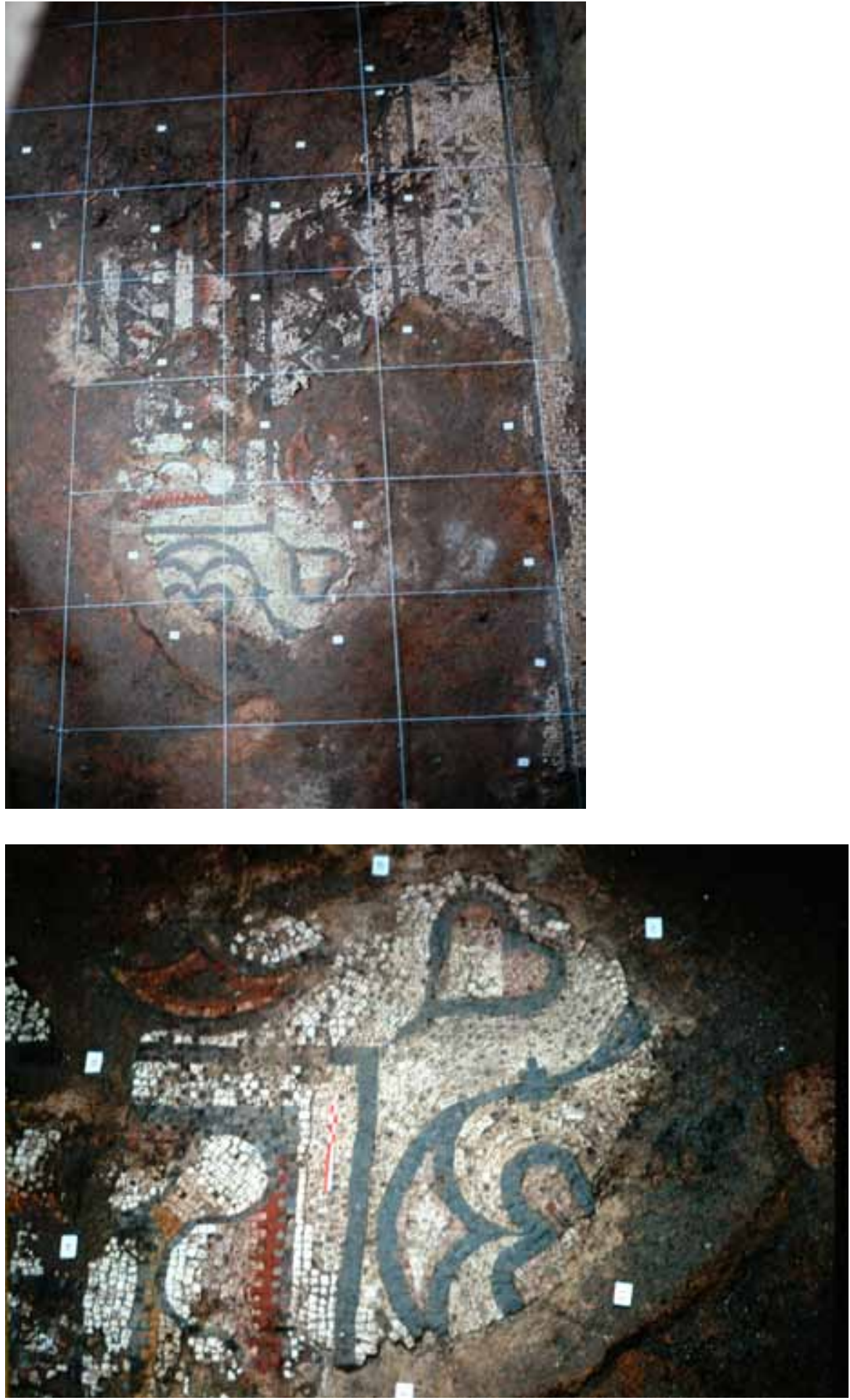

from the uillae of Los Quintanares and Santervás del Burgo. In this last case the peltae band is associated with a narrow frame of polychrome tangent juxtaposed bells ${ }^{10}$, as it appears in the mosaic of the "House of the Wheel".

In relation to the detail of the modus faciendi of the peltae junction, this could indicate the use by the mosaicists of the same model that, in this particular

10 See Blázquez - Ortego 1983: 27-28 lám. 28 mosaic n. 14 from Los Quintanares; Blázquez - Ortego 1983: 41-42 lám.14 mosaic n. 37 from Santervás del Burgo. 
decoration, is used in Braga and the mosaics of Soria. It is important to highlight the existence, in the aforementioned Hispanic regions, of the Roman roads Asturica-Caesaraugustana and Bracara-Asturica which would have been important vehicles of circulation for models and mosaicists. Such exchanges would have allowed the repetition of the procedure regarding the peltae junction in the aforementioned mosaics of the Villa of Quinta das Longas, Conuentus emeriten$\operatorname{sis}^{11}$.

In regard to parallels in the eastern part of the Empire, a similar frame to the mosaic from the "House of the Wheel" is found in Apollonia (in modern-day Albania), involving squares from the mosaic field, dating from the third century AD (Anamali - Adhami 1974: 41-42) (Figs. 14- 15).

The other two frames present in the mosaic of the "House of the Wheel" are decorated with an "undulating polychrome band" (Décor I: pl. 60e, polychrome variety; Viegas et al. 1993: 74), simplified designation used by Cristina Oliveira (Oliveira 2003: 98ff), and with «a row of tangent cuboids with serrated sides" (Décor I: pl. 99f; Viegas et al. 1993: 96) ${ }^{12}$. These geometric themes of a pictorial/ volumetric nature refer us to Greek and Hellenistic mosaic. About them, we can highlight the following:

- The row of tangent juxtaposed shaded bells, forming tangent inverted bells and an undulating line, possible derivation from the ribbon, which visually connects to the row of adjacent calices, alternately inverted, horizontally shaded in late performances (Oliveira 2003: 98), in the mosaic of the "House of the Wheel" presents little volume if compared, for example, with the undulating polychrome bands carried out in the mosaics from the Villa of Santiago da Guarda, Ansião, Leiria or from the "House of the Medusa" in Alter do Chão, in the frame surrounding the figured panel of the triclinium. The one from the mosaic of the "House of the Wheel", among other Hispanic examples ${ }^{13}$, is compared to the undulating polychrome bands used in some panels of the œcus mosaic from the Domus Oceani of Lugo, dated from the same period of the mosaic from Braga (González Fernandez 2005: 94, 103, 128 figs. 104, 105, 124). If we take into account, in addition to the geographical proximity of the two cities, the possible existence of an itinerant officina, active in the second half of the third century, in the area of the Roman road which connected Lucus to Bracara Augusta (Balil 1975: 262), we can consider these creations as coming from the same officina.

In Portuguese mosaics, this decoration presents a wide geographical distribution, being used both in panel frames, as defining the geometric figures of the mosaic field or even as surrounding some of the geometric figures from the surface

11 Oliveira et al. 2011: 907 consider that the peltae with trilobe leaves on the central point featured in the mosaics from rooms 12 and 17 of the uilla of Quinta da Longas can be a distinguishing mark of the officina that carried them out, since the possible model from Merida from the fourth century presents the peltae decorated with simple heart leaves. However, we can consider it an interchange of "models" or mosaic makers among officinae, since we note a parallel for the trilobe leave, in the angle of a frame of peltae alternately inverted, in a mosaic from Albalate of Cinca, Province of Huesca, dating from the last quarter of the fourth century (Fernandez-Galiano 1987: 62-63 lám. 29 mosaic n. 96). The relationship between a mosaic from the uilla of Quinta das Longas (mosaic from room $\mathrm{n} .5$ with a crismon) and a mosaic of the Villa of Fortunatus, also in the Hispanic Province of Huesca, is pointed out by Oliveira et al.2011: 908. So we can see particular procedures, as the connection of the peltae and the trilobe leaves in mosaics from Braga, Los Quintanares and Santervás del Burgo, Quinta das Longas, Albalate of Cinca, procedures that can be more exchanges than distinguish marks of officinae.

12 These two decorative themes in bands occurring in Portuguese Roman mosaics were specifically handled in the presentation we gave in the XIII AIEMA Congress, Madrid, 2015.

13 The "undulating row of tangent juxtaposed bells", bichrome or polychrome, is common in Hispanic mosaics, being the polychromatic variety a characteristic of the later mosaics. Both in Portuguese territory, as well as in Spanish, its occurrence has a wide geographical distribution. 
Figure 14

Detail of the band with polychromatic inverted bells of the mosaic from the "Casa da Roda". (C) AFMDDS
Figure 15

Detail of the band with tangent cuboids of the mosaic from the "Casa da Roda". (c) AFMDDS.
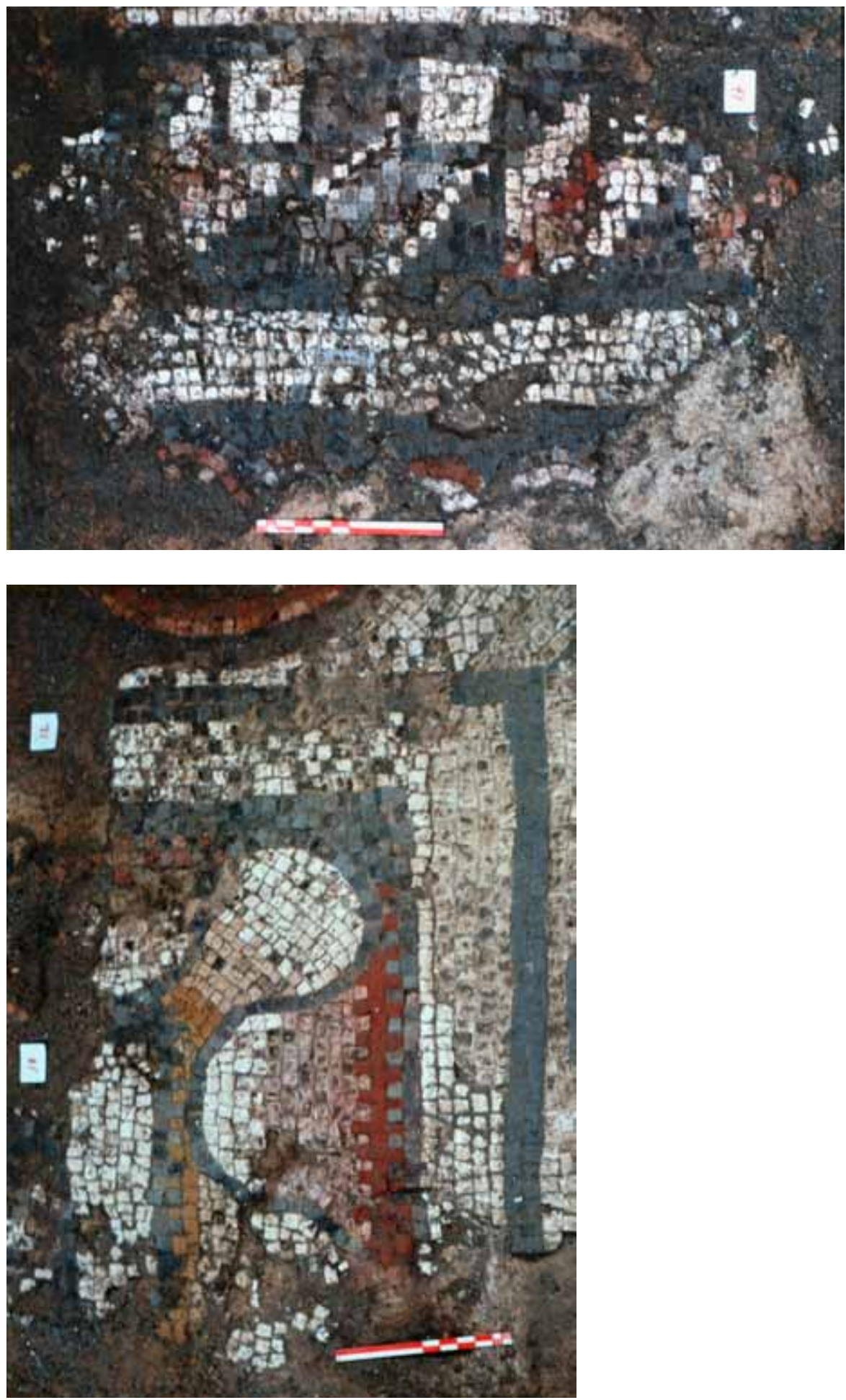

compositions. In a mosaic from the Villa of Milreu, Estói, Faro, a polychrome undulating band fills a rectangle framed by a simple guilloche of a panel at the entrance of the domus (Lancha - Oliveira 2013: 224-229).

Cristina Oliveira (Oliveira 2003: 100; Oliveira et al. 2011: 908; Lancha Oliveira 2013: 229) mentions, apart from some of the mosaics from the Villa of Rio Maior, other Portuguese archaeological sites where this type of mosaic decoration occurs: the Villa of Prado Galego, Pinhel; the Villa of San Pedro de Caldelas, Tomar, Conuentus Scalabitanus; the Villa of Quinta Longas, 
Conuentus Emeritensis and, in Conuentus Pacensis, the Villa of Monte do Meio, Beja, and a mosaic coming from Lagos, in a bicolour version of the undulating band (Lancha - Oliveira 2013: 228-229) ${ }^{14}$.

- The row of tangent cuboids (Décor I: pl. 99e; Viegas et al. 1993: 96) ${ }^{15}$ also occurs in mosaics from the Villae of Rabaçal, Penela, Coimbra and from Santiago da Guarda, Ansião, Leiria, both integrated in the Conuentus Scalabitanus. Used in frames, the solids are aligned, either all facing the angles of the square polygon which they involve, as in this mosaic of the "House of the Wheel", in Santiago da Guarda and in one of the mosaics from the Villa of Rabaçal, or they are placed converging to the midpoint of the frame (as in other mosaics from the Villa of Rabaçal).

In Spain, this geometric decoration occurs with a wide geographical dispersion, although it seems more frequent in later mosaics from the Meseta.

Among other parallels present in mosaics of late Hispanic uillae, we can point the mosaic of Bellerophon and the Chimera of Bell-Lloch (Gerona) from the mid-third century; mosaics from the fourth century, as the ones from Quintanares of Soria (Blázquez - Ortego 1983: 13 lam. 7 mosaic n. 13), from Carranque (Toledo), in the mosaic of the Ocean (Fernández-Galiano et al. 1994: 325 fig. 6) or the mosaic of Atalanta and Meleagro from Cardeñajimeno (Burgos), from the late fourth century (Monteagudo et al. 1998: 21-28; 35-42 fig. 5 lams. 7-12, mosaic n. 9) ${ }^{16}$.

This type of decoration is also quite common in North African and East Mediterranean mosaics, including those from Antioch and Zeugma, dating from the second-third century and later ${ }^{17}$, or those from Apamea, in Syria (Balty 1977: 90-91).

In regard to the Portuguese Roman mosaics with this frame decoration, it is possible to observe that, as far as we know, in contrast with the dispersion of polychrome undulating bands, the bands with tangent cuboids are concentrated in mosaics from the Conuenteus Scalabitanus ${ }^{18}$, widening, with the mosaic from the "House of the Wheel", to the Conuentus Bracaraugustanus.

In this late mosaic from Braga, the row of cuboids, a representation already very distant from the architectural cornice which would have inspired it, is associated with the decoration of the polychrome undulating band that is also quite distant from the volume of the ribbon which could have been in its origin.

14 Oliveira refers the example of this dichromatic variety of the undulating band, originating from the House of Mitreo, in Merida, from the second century (quoting Freijeiro 1978: 38-39 n. 18). For the polychromic version, several examples from the African provinces are pointed out, especially from the period of its greatest expansion, in the third and fourth centuries. See, also, Oliveira 2003: 98-101.

15 This theme should be distinguished from the "row of consoles in lateral perspective" (Décor I: pl. 99i; Viegas et al. 1993: 27), as it appears in two mosaic floors from Conimbriga, dating from the second century, which are exhibited at the entrance of the Ruins of Conímbriga. Oleiro1973: 76-110 dates the mosaic, which later was considered to have paved the cenatio of the "House of Cantaber", from the middle or third quarter of the second century, with reserves (p. 92) and the mosaic, whose original location is unknown, from the end of the Antonine period (p. 110). See also Oliveira 2005: 51 mosaic n. 32 (from the "House of Cantaber"); 84 mosaic n. 60 (from an unknown location).

16 The examples referred to by the authors concerning the mosaic study from Cardeñajimeno, n. 9.

17 See Cimok 2000: 79, 81, 83, 92, among other examples.

18 The use of isolated solids, placed in the centre of the squares of a surface composition, occurs in a mosaic from the Villa of Coriscada, Meda, Guarda (Légier 2015: 191). 


\section{Final Considerations}

Taking into account the work developed and published by the Recovery Team of Bracara Augusta, it is possible to conclude that the period corresponding to the end of the third century-early fourth century represents a period of great constructive activity in Bracara Augusta, confirming numerous renovations in many buildings and also registering great transformations in the urban layout.

In the excavations carried out in the various archaeological sites where the above mentioned mosaics were found, archaeologists have found that they relate to a remodelling phase attributed, generically, to the late Antiquity. This phase would have been contemporary to the great transformations of Braga's urban area, associated with the construction of the first Paleo-Christian Basilica on the site of the current Cathedral, during the fifth century. This fact would have determined the concentration of the urban fabric in the northeast quadrant of the city and the abandonment of some central and southern areas of the ancient Roman city (Leite et al. 2012: 42).

As for the decorative grammar present in mosaics from the region of Braga, it is noted that, for the most part, it consists of geometrical and vegetal motifs, but five archaeological sites that feature mosaics decorated with marine fauna are also known. To the figurative motifs, it is possible to add the fragment decorated with the crater.

This decorative grammar of Hispanic, North African and Eastern Mediterranean inspiration features in local particularities of Bracara Augusta. The crossroads of influences present in the mosaics of Braga were certainly consolidated by the relationships of this northwest region with southern Hispania, made through the Atlantic route.

\section{Acknowledgements to:}

The Director of the D. Diogo de Sousa Museum, Isabel Silva and her team: Maria José Sousa, Manuel dos Santos, Isabel Marques, Vítor Hugo, Felismina Vilas Boas, Filipe Antunes, Amélia Marques and Paula Góis.

All the members of the Recovery Project of Bracara Augusta, under the direction of Manuela Martins and Luís Fontes from the Archaeology Unit of the University of Minho and the archaeologist for the City Council of Braga, Armandino Cunha. 


\section{Bibliography - Kaynaklar}

Abraços 2005

Abraços 2008

Abraços 2011

Abraços 2014

Abraços 2015

Abraços 2015a

Abraços in print

Alexander - Ennaïfer 1975

Alexander et al. 1980

Anamali - Adhami 1974

António 2015

Balil 1975

Balty 1977

Balty 1995

Barral i Altet 1975

Blázquez 1982

Blázquez - Mezquiriz 1985

Blázquez - Ortego 1983

Blázquez et al. 1993

Cimok 2000

Correia Wrench 2005

Costa 1905

Décor I

Décor II
M. de F. Abraços, Para a História da conservação e restauro do mosaico romano em Portugal (I-II-III), Ph.D. Thesis, Faculdade de Letras da Universidade Clássica de Lisboa, Lisboa.

M. de F. Abraços, "Conservation et restauration des mosaïques romaines au Portugal - Quelques exemples dans les collections de musées", The $9^{\text {th }}$ Conference of the International Committee for the Conservation of Mosaics, 2005, Lessons learned: reflecting on the Theory and practice of mosaic conservation, Tunisia, Getty Publications, 69-74.

M. de F. Abraços, "Os mosaicos romanos de Bracara Augusta da colecção do Museu Regional de Arqueologia D. Diogo de Sousa, Braga”, Actas do X Colóquio do Mosaico Greco-Romano: O mosaico romano nos centros e nas periferias. Originalidades, influências e identidades, AIEMA, Conímbriga, 827-835.

M. de F. Abraços, "The Mosaics with Geometric Patterns from the West and the East of the Roman Empire: The Hourglass Pattern and the Significance of the "Le Décor Géometrique de la Mosaïque Romaine I-II", JMR 7, 1-9.

M. de F. Abraços, "Roman Mosaics of Bracara Augusta. Basins: aspects of iconography”, XII Colloquio AIEMA: ATTI, Verona: Scripta Edizioni, 481-484.

M. de F. Abraços, "Os mosaicos de Bracara Augusta. Itinerários de divulgação", Actas do Encontro PortugalGaliza: Mosaicos Romanos. Fragmentos de Cultura nas Proximidades do Atlântico, APECMA/AIEMA, 134-149.

M. de F. Abraços, "The high Imperial mosaics of the oldest Roman house in Bracara Augusta", Saeculum Augustum, New approaches to the Age of Augustus on the bimillenium of his death, Georg Olms Publisher.

M. Alexander - M. Ennaïfer, "Quelques précisions à propos de la chronologie des mosaïques d’Utique (un chapitre du Corpus des Mosaïques de Tunisie)”, CMGR II, 31-38.

M. A. Alexander - A. Ben Abed (coll. S. Besrour-Ben Mansour - D. Soren et al.) Corpus Tunisie II, I Tunis, Institut National d'Archéologie et d'Art.

S. Anamali - S. Adhami, Mosaïques de L'Albanie, Tirana.

J. António, "Mosaicos geométricos da Casa da Medusa", Abelterium - Revista online de Arqueologia e História do Município de Alter do Chão, Vol. II/Número I/Maio/2015, Edição Alter do Chão, 39-51. (http://www.cm-alter-chao.pt/pt/abelterivm).

A. Balil, "Sobre los Mosaicos Romanos de Galicia: Identificación de un Taller Musivario”, CMGR II, 259-263.

J. Balty, Mosaïques Antiques de Syrie, Bruxelles, Centre Belge de Recherches Archéologique à Apamée de Syrie - Musées royaux d'art et d'histoire, Bruxelles.

J. Balty, Mosaïques Antiques du Proche Orient. Chronologie, iconographie, interprétation, Besançon, Université.

X. Barral i Altet, "Les mosaïques de l'ancien siège épiscopale d'Egara (Terrassa) en Catalogne", CMGR II, 241-258.

J. M. Blázquez, Corpus España V, Mosaicos Romanos de La Real Academia de la Historia, Ciudad Real, Toledo, Madrid y Cuenca, Madrid, CSIC.

J. M. Blázquez - M. A. Mezquiriz, Corpus España VII, Mosaicos Romanos de Navarra, Madrid, CSIC.

J. M. Blázquez - T. Ortego, Corpus España VI, Mosaicos de Soria, Madrid, CSIC.

J. M. Blázquez - G. López Monteagudo - T. Mañanes - C. Fernández Ochoa, Corpus España X, Mosaicos Romanos de León y Asturias, Madrid, CSIC.

F. Cimok, A Corpus of Antioch Mosaics, İstanbul, A Turizm Yayınları.

L. N. Correia Wrench, Decoração Vegetalista nos Mosaicos Portugueses, Lisboa, Edições Colibri / Instituto de História da Arte, Faculdade de Ciências Sociais e Humanas - UNL.

A. I. Marques da Costa, "Mosaicos romanos de Portugal. Dois mosaicos romanos achados nas proximidades de Leiria”, O Arqueólogo Português X, 49-50.

C. Balmelle - M. Blanchard Lemée - J.Christophe - J. P. Darmon - A. M. Guimier Sorbets - H. Lavagne R. Prudhomme - H. Stern, Le Décor Géométrique De La Mosaïque Romaine I, Picard Editeur, Paris, 1985.

C. Balmelle - M. Blanchard Lemée - J. P. Darmon - S. Gozlan - M.P. Raynaud, Le Décor Géométrique De La Mosaïque Romaine II, Picard Editeur, Paris, 2002. 
Fernández-Galiano 1984

Fernández-Galiano 1987

Freijeiro 1978

González Fernández 2015

Lancha 1977

Lancha - Oliveira 2013

Légier 2015

Leite et al. 2012

Levi 1947

Lopes 2003

Lopes 2015

Maciel 1996

Magalhães 2010

Martins 2000

Martins et al. 2012

Mezquíriz 2004

Monteagudo et al. 1998

Oleiro 1973

Oliveira 2003

Oliveira 2005

Oliveira et al. 2011

Pereira 2008

Pessoa 1998

Pessoa 2011

Ribeiro 2008

Ribeiro 2015

Torres Carro 1988
D. Fernández-Galiano, Excavaciones Arqueológicas en España - COMPLUTUM II, Mosaicos, Ministério de Cultura. Direccion General de Bellas Artes y Archivos.

D. Fernández-Galiano, Mosaicos Romanos del Convento Cesaraugustano, Zaragoza, Caja de Ahorros de Zaragoza, Argon y Rioja.

A. Blanco Freijeiro, Corpus España I, Mosaicos Romanos de Mérida, Madrid, CSIC.

E. González Fernández, DOMVS OCEANI. Aproximación á arquitectura doméstica de Lucus Augusti, Traballos de Arqueoloxía, 2, Lugo, Concello de Lugo.

J. Lancha, Mosaïques Géométriques. Les ateliers de Vienne (Isère). Leurs modèles et leur originalité dans l'Empire romain, Roma, « L'ERMA » di Bretschneider.

J. Lancha - C. Oliveira, Corpus dos Mosaicos Romanos de Portugal - Algarve Este, II Conventus Pacensis, 2 Algarve Este, Faro, Universidade do Algarve.

M. Légier, "Les mosaïques de Coriscada, Vale de Mouro, Meda, Portugal”, Actas Encontro Portugal- Galiza: Mosaicos Romanos. Fragmentos de Cultura nas Proximidades do Atlântico, APECMA/AIEMA, 187-194.

J. M. Leite - L. Fontes - M. Martins - J. Tomé - D. Mendes, Salvamento de Bracara Augusta, Trabalhos Arqueológicos da UAUM/Memórias, 25, Relatório final de escavação, Unidade de Arqueologia da Universidade do Minho.

D. Levi, Antioch Mosaic Pavements, Princeton.

V. Lopes, Mértola na Antiguidade Tardia. A topografia histórica da cidade e do seu território nos alvores do cristianismo, Mértola, Campo Arqueológico de Mértola.

V. Lopes, “Os Mosaicos nas Cidades Portuárias Hispânicas na Antiguidade Tardia”, Actas Encontro PortugalGaliza: Fragmentos de Cultura nas Proximidades do Atlântico APECMA/AIEMA, 19-32.

M. J. Maciel, Antiguidade Tardia e Paleocristianismo em Portugal, Lisboa.

F. E. P. de Magalhães, Arquitectura doméstica em Bracara Augusta, Tese de Mestrado Arqueologia, Universidade do Minho, Instituto de Ciências Sociais.

M. Martins, "Bracara Augusta Revisitada", Bracara Augusta XLIX, 103-116.

M. Martins - J. Ribeiro - F. Magalhães - C. Braga, "Urbanismo e Arquitectura de Bracara Augusta. Sociedade, economia e lazer", Evolução da paisagem urbana, Sociedade e Economia. Braga, 29-68.

M.Á. Mezquíriz, "Los mosaicos de la villa romana de Liédna (Navarra)", Trabajos de Arqueología. Navarra/17. Homenaje a Ma Ángeles Mezquíriz Irujo. Gobierno de Navarra. Pamplona 2004 (2004 Arqueologia Navarra), 327-359.

G. López Monteagudo - R. Navarro Sáez - P. Palol Salellas, Corpus España XII, Mosaicos Romanos de Burgos, Madrid, CSIC.

J. M. B. Oleiro, "Mosaicos de Conímbriga encontrados durante as sondagens de 1899", Conimbriga 12, 67-158.

C. F. de Oliveira, A villa romana de Rio Maior: estudo de mosaicos, Lisboa, Ministério da Cultura, Instituto Português de Arqueologia (Trabalhos de Arqueologia 31).

C. Oliveira, Mosaicos de Conímbriga, AIEMA X Colóquio Internacional, Conímbriga, Instituto Português de Museus/Museu Monográfico de Conímbriga.

C. Oliveira - A. Carvalho - M. J. de Almeida, "La villa de Quinta das Longas (Elvas-Portugal): les mosaïques du Bas-Empire", CMGR X, 903-914.

R. M. Pereira, "Resultados dos Trabalhos Arqueológicos no Paço de Vasconcelos em Santiago da Guarda (Maio de 2002 a Julho de 2004)", CEP-UA, Actas do IV Congresso de Arqueologia Peninsular. Hispânia Romana (Faro, 14-19 de Set. 2004). Faro: Centro de Estudos de Património-Universidade do Algarve, 171-181.

M. Pessoa, Villa Romana do Rabaçal. Um objecto de Arte na Paisagem, Penela, Câmara Municipal de Penela.

M. Pessoa, Villa Romana do Rabaçal. Estudo de Mosaicos, Ph.D. Thesis, Faculdade de Ciências Sociais e Humanas, Universidade Nova de Lisboa, Lisboa.

M. do C. Ribeiro, Braga entre a época romana e a idade moderna, Ph.D. Thesis, Universidade do Minho, Braga (Repositório da Universidade do Minho).

L. C. Ribeiro, "Contributo para uma visão global dos pavimentos de mosaico da Villa romana de Santiago da Guarda, Ansião", Actas do Encontro Portugal-Galiza: Mosaicos Romanos. Fragmentos de Cultura nas Proximidades do Atlântico, APECMA/AIEMA, 71-91.

M. Torres Carro, "Los Mosaicos de la Villa de Prado", BSAA LIV, 175-218. 
Torres Carro 2015

Wrench 2014

Wrench in print

Viegas et al. 1993
M. Torres Carro, "A Propósito del análisis de la estructura geométrica de la decoración del mosaico de la antesala del oecus de la Domus Oceani de Lugo", Actas do Encontro Portugal-Galiza: Mosaicos Romanos. Fragmentos de Cultura nas Proximidades do Atlântico Edição da APECMA/AIEMA, 336-338.

L. N. C. Wrench, "Some Geometrical Patterns and Decorative Motifs occurring in Roman Portuguese Mosaic: A Comparative Approach with Eastern and Western Mosaics", JMR 7, 49-59.

L. Wrench, "A mosaic from the «Casa da Roda»", Saeculum Augustum, New approaches to the Age of Augustus on the bimillenium of his death, Georg Olms Publisher.

C. Viegas - F. Abraços - M. Macedo, Dicionário de Motivos Geométricos no Mosaico Romano, Conímbriga, Liga dos Amigos de Conímbriga.

\section{Abbreviations used in the text}

AFMDDS

AIEMA

AMDDS

MDDS

MMSR

APECMA

ICCM
Photogrphic Archive of D. Diogo de Sousa Museum

Association Internationale pour l'Étude de la Mosaïque Antique

Archive of D. Diogo de Sousa Museum

D. Diogo de Sousa Museum of Braga

Santos Rocha Municipal Museum of Figueira da Foz

Portuguese Association for the Study and Conservation of Ancient Mosaic

International Committee for the Conservation of Mosaics 